\title{
Pharmaciana
}

Vol.10, No.3, Nov 2020, Page. 371-380

ISSN: 2088 4559; e-ISSN: 24770256

DOI: $10.12928 /$ pharmaciana.v10i3.17780

\section{Antioxidant activity and sun protection factor evaluation for cream formulation of purified roasted corn silk (Zea Mays L. Saccharata) extracts}

\author{
Munifatul Lailiyah", Sony Andika Saputra, Fita Sari \\ Institut Ilmu Kesehatan Bhakti Wiyata Kediri \\ Jl. KH Wachid Hasyim No.65, Bandar Lor, Kec. Mojoroto, Kediri, East Java, Indonesia
}

Submitted: 22-09-2020

Reviewed: 28-09-2020

Accepted: 17-10-2020

\begin{abstract}
Free radicals might cause harmful effects on the skin, such as skin irritation, change of skin color, and worst effect. Phenolics play a role as effective sunscreen and antioxidants to prevent UV radiation effects. Corn silk contains flavonoids, which are antioxidants that are potential as sunscreen. Phenolic compounds can be identified by phytochemical screening using the tube method. The study aimed to determine the antioxidant activity of purified extract of roasted corn silks (Zea Mays L. saccharata) and the SPF level of the cream preparation. The study was conducted by collecting samples of roasted corn silks waste to make dried simplicial, then extracting it with $70 \%$ ethanol as solvent, evaporated till condensed extract is gotten. The obtained extract was then purified with nhexane solvent. The antioxidant activity test was conducted by using the DPPH method. The cream of the purified extract was made in three formulations: $1 \%, 5 \%$, and $10 \%$ concentration. Its SPF levels were then evaluated. The results showed the purified corn silks extract had an $\mathrm{IC}_{50}$ value of 256.66 $\mu \mathrm{g} / \mathrm{mL}$ better compared to corn silks ethanol extract having an $\mathrm{IC}_{50}$ value of $356.17 \mu \mathrm{g} / \mathrm{mL}$ including the weak antioxidant category. Meanwhile, the SPF level test results for concentration of $1 \%, 5 \%$, and $10 \%$ were $1.27 ; 2.41$; and 5.94 respectively.
\end{abstract}

Keywords: corn silks, purified, antioxidants

\footnotetext{
*Corresponding author:

Munifatul Lailiyah

Institut Ilmu Kesehatan Bhakti Wiyata Kediri,

J1. KH Wachid Hasyim No.65, Bandar Lor, Kec. Mojoroto, Kediri, East Java, Indonesia

Email: Munifatul.lailiyah@yahoo.com
} 


\section{INTRODUCTION}

The use of plants as cosmetic ingredients is an excellent opportunity for the community to develop natural ingredients potential. Skin health needs to be maintained so that it is not damaged by exposure to solar radiation. Ultraviolet (UV) rays of the sun can accelerate the aging process of the skin. This process is cumulative. Chronic reactions from sun exposure to ultraviolet rays over the years can cause structural skin disorders, especially premature aging of the skin, as well as skin cancer (Walker et al., 2003). The damage caused can be seen clinically, histopathologically, and functionally (Berneburg et al., 2000).

Natural compounds that are reported to act as anti-aging are compounds with aromatic rings such as phenolic groups, especially flavonoids (Maheshwar et al., 2010).One of the plants reported to contain phenolics is corn silk. Corn silk is rich in phenolics, especially flavonoids (Liu et al., 2011). Phenolics are compounds that have one or more hydroxyl groups that are directly attached to aromatic rings. Phenol or carbolic acid is the structure that underlies all the groups of these compounds in which the aromatic ring is benzene (Scalbert and Williamson, 2000). The test results for the antioxidant activity of the ethanol extract of corn hair had an $\mathrm{IC}_{50}$ value of $143.55 \mu \mathrm{g} / \mathrm{mL}$ (Nurhanan and Rosli, 2012). The SPF level of fractionation of the ethanol extract of corn silk was 9-25 (Laeliocattleya and Jati, 2014).

Cosmetic preparation preferred by the public, especially women, is cream. Cream preparation is used as a protector for the outer skin layer so that it is protected from sun exposure that can easily damage skin tissues. Other benefits of cream preparations are comfortable to wear, not sticky, and easy to wash by water (Rabima and Marshall, 2017).

So far, the waste of corn silks has not been fully utilized, especially the waste from roasted corn silks (Zea Mays L. saccharata) at the Taman Sekar Taji Roundabout, Kediri. The purified extract of roasted corn silk obtained is formulated into antioxidant creams and sunscreens. The form of purification was chosen to obtain secondary metabolite compounds that are more specific from corn silk waste. The determination of antioxidant activity was carried out using the Diphenylhydrazylpicryl (DPPH) method and the determination of the SPF (Sun Protection Factor) level using the spectrophotometric method.

\section{MATERIALS AND METHOD \\ Materials}

The material used in this study is the waste silk of roasted corn (Zea Mays L. Sacharata) in the Taman Sekar Taji roundabout, Kediri City.

\section{Methods}

\section{Simplicia preparation}

Samples were sorted, then washed, chopped, dried for three days by aerating them, keeping them away from direct sunlight, then milled (Laeliocattleya and Jati, 2014).

\section{Extraction of corn silks}

Corn silk extract was made by maceration: simplicia of corn silk were weighed for $100 \mathrm{~g}$ then extracted with $750 \mathrm{~mL}$ of $70 \%$ ethanol by maceration for five days protected from light, after five days of straining. The filtrate was collected, and the residue was added with $70 \%$ ethanol as much as 250 $\mathrm{mL}$, then re-filtered. The filtrate from the maceration results was then evaporated in a rotary evaporator then concentrated in a water bath until a condensed extract was obtained (Nurhanan and Rosli, 2012). 


\section{Purified extract}

The condensed extract of corn silk was purified by using n-hexane as a solvent. A total of 20 grams of condensed corn silk extract was dissolved using $70 \%$ ethanol in a ratio of 1:10, then was put in a separating funnel, shaken until become homogeneous. Then, $n$-hexane was added with a solvent ratio of 1:2, extracted to form 2 phase layers of ethanol and $n$-hexane, where this process was repeated until the n-hexane phase looks clear. The separated solution was concentrated in a rotary evaporator with a temperature of $60^{\circ} \mathrm{C}$ until purified extract was obtained (Zhang et al., 2005).

\section{Phytochemical test of cornsilk purified extract}

The purified extract of corn silk was tested for the content of secondary metabolites of flavonoids, alkaloids, tannins, and saponins qualitatively by the tube method. In this method, the identification of flavonoids was conducted using $0.1 \mathrm{~g}$ of the sample plus $3 \mathrm{~mL}$ of $70 \%$ ethanol, shaken, filtered then added 2 drops of $\mathrm{Mg}$ and 2 drops of concentrated $\mathrm{HCl}$. In this stage, the flavonoid was identified using $0.1 \mathrm{~g}$ tannin in the sample was added with $5 \mathrm{~mL}$ of boiled aquadest, then filtered and added $1 \% \mathrm{FeCl}_{3}$. Identify $0.1 \mathrm{~g}$ saponin sample plus $5 \mathrm{ml}$ of heated aquadest. After that, it was filtered and shook to observe the formation of foam. The identified alkaloids in the $0.1 \mathrm{~g}$ sample were added with the reagents of Mayer, dragendorff, and Wagner (Nariya et al., 2013).

\section{Antioxidant activity test by DPPH method}

A solution of $0.4 \mathrm{mM}$ DPPH was made by dissolving $15.8 \mathrm{mg}$ of DPPH powder in $100.0 \mathrm{~mL}$ methanol. The extract and the purified extract of corn silk were dissolved in methanol with $1 \mu \mathrm{g} / \mathrm{mL}$ concentration, and the series of dilution was held until $0,05 \mu \mathrm{g} / \mathrm{mL}, 0,2 \mu \mathrm{g} / \mathrm{mL}, 0,4 \mu \mathrm{g} / \mathrm{mL}, 0,6 \mu \mathrm{g} / \mathrm{mL}$ concentrations were obtained. As much as $1.0 \mathrm{~mL}$ of $0.4 \mathrm{mM}$ DPPH was added into each volumetric flasks, and methanol was added until $10.0 \mathrm{~mL}$ volume was obtained, stirred till it becomes homogenous. The next step was measuring the absorbance of the sample at a wavelength of $500-524$ $\mathrm{nm}$. The obtained absorbency data are then substituted into the equation (1) and followed by linear regression.

$$
\% \text { inhibition }=\frac{\text { Abs control }- \text { Abs sample }}{\text { Abs control }} \times 100 \%
$$

The linear regression equation was calculated by entering the concentration series (ppm) as $\mathrm{X}$ and the percent inhibition (\%) as $\mathrm{Y}$ so that the equation: $\mathrm{Y}=\mathrm{bx}+\mathrm{a}$ was obtained. The $\mathrm{X}$ value was changed to 50 to obtain the $\mathrm{IC}_{50}$ value. Thus, a sample concentration was obtained to reduce $50 \%$ of DPPH free radicals (Badarinath et al., 2010).

\section{Purified corn silk extract cream production}

All required materials were weighed. Materials needed for the formulation were separated into two groups: the oily phase and the watery phase. The oily phase group, which consists of stearate acid $5 \mathrm{~g}$, cetyl alcohol $3 \mathrm{~g}$, liquid paraffin $7 \mathrm{~g}$, olive oil $10 \mathrm{~g}$, and nipagin $0,0025 \mathrm{~g}$, was melted on the water heater at $70^{\circ} \mathrm{C}-75^{\circ} \mathrm{C}$. Meanwhile, the watery phase group, which consists of TEA $1 \mathrm{~g}$, glycerin $7 \mathrm{~g}$, and Nipasol (propylparaben) 0,015g, was dissolved in hot aqua dest (distilled water). The watery phase group was crushed in a hot mortar; then, the oily phase group was gradually added while stirred until it becomes homogenous, and the cream mass was obtained. The purified extract of corn silk formulation 1 as much $1 \mathrm{~g}$, as was added and gradually crushed until it became homogenous. The same way was conducted on formulations 2 and 3 (Ekowati and Ningsih, 2014). The formulation of the antiaging cream made of purified corn silk extract can be seen in Table 1. 
Table 1. Cream formulation of purified corn silk extract

\begin{tabular}{lccc}
\hline \multirow{2}{*}{ Formula } & \multicolumn{3}{c}{ Composition (Gram) } \\
\cline { 2 - 4 } & F1 & F2 & F3 \\
\hline Purified corn silk extract & 1 & 5 & 10 \\
Stearate acid & 5 & 5 & 5 \\
Cetyl alcohol & 3 & 3 & 3 \\
TEA & 1 & 1 & 1 \\
Liquid paraffin & 7 & 7 & 7 \\
Olive oil & 10 & 10 & 10 \\
Glycerin & 7 & 7 & 7 \\
Nipagin & 0.025 & 0.025 & 0.025 \\
Nipasol & 0.015 & 0.015 & 0.015 \\
Aquadest & 65,96 & 61,96 & 52,96 \\
Total weight & 100 & 100 & 100 \\
\hline
\end{tabular}

\section{Physical quality test of corn silk purified extract cream}

The physical quality test of purified corn silk extract cream included organoleptic, $\mathrm{pH}$, homogeneity, spreadability, adhesion, and cream type. Organoleptic testing was carried out by observing the shape, color, and smell of the cream. The degree of acidity $(\mathrm{pH})$ was determined using a $\mathrm{pH}$ meter calibrated in advance with standard buffer solutions of $\mathrm{pH} 4$ and 7 . The homogeneity test was conducted by taking enough cream smeared on the glass or object-glass, if there were no lumps then the cream was homogeneous. Testing the spreadability of the cream, weighed $0.5 \mathrm{~g}$ of cream, placed between 2 layers of glass object that was given a load of $100 \mathrm{~g}$, measuring the diameter of the cream was carried out after approximately 1 minute. The adhesion test was weighed with $0.5 \mathrm{~g}$ of cream placed between the two slides then given a load of $1 \mathrm{~kg}$ for 5 minutes. (Bernatoniene et al., 2011). The two objects were separated by pulling the slide on top with a weight of $80 \mathrm{~g}$, while the screwdriver below was held up by another load. The length of time was taken to separate the two objects was recorded as sticky time. Test the type of cream using conductivity, one end of the tool was put in the cream then the tool was plugged into the socket. If the lamp in the tool was on, it indicates that the cream was a type of oil in water (O / W) (Damogalad et al., 2013).

\section{Purified corn silk extract cream determination of SPF level}

The SPF level was determined by using UV spectrophotometry. Cream of purified corn silk extract was diluted with $70 \%$ ethanol in a $10 \mathrm{~mL}$ flask to obtain $1000 \mu \mathrm{g} / \mathrm{mL}$ concentration, then diluted to a concentration of $100 \mu \mathrm{g} / \mathrm{mL}$. First, the UV-Vis spectrophotometer is calibrated using $1 \mathrm{~mL}$ of ethanol. The diluted solution was measured for its absorbance at $\lambda 290-320 \mathrm{~nm}$ with a measurement interval of $5 \mathrm{~nm}$. The absorbance and the SPF value were then calculated (Dutra et al., 2004). The test was conducted for three times to get an accurate value and calculatet using equation 2 .

$$
\text { Value SPF }=C F x \sum_{a 20}^{290} A b s x E E x I
$$

Description: $\mathrm{EE}=$ Erythemal effect spectrum, $\mathrm{I}=$ light spectrum intensity, Abs = screen product absorption, $\mathrm{CF}=$ correlation factor (Molyneux, 2004). The value of EE x 1 was a constant, obtained from the wavelength $290-320 \mathrm{~nm}$ and any $5 \mathrm{~nm}$ difference had been determined as shown in Table 2 . 
Table 2. EE and I constants for the calculation of SPF

\begin{tabular}{cc}
\hline Wavelength $(\mathbf{n m})$ & EE x 1 \\
\hline 290 & 0.0150 \\
295 & 0.0817 \\
300 & 0.2874 \\
305 & 0.3278 \\
310 & 0.1864 \\
315 & 0.0839 \\
320 & 0.0180 \\
\hline
\end{tabular}

SPF values range from 0 - 100, and a sunscreen considered good is above 15 (Nguyen and Rigel, 2005).

\section{Data Analysis}

The data analysis of the results of this study included the phytochemical content of the purified corn silk extract, comparing the $\mathrm{IC}_{50}$ value of the extract compared with the $\mathrm{IC}_{50}$ value of the purified corn silk extract using paired sample t-test analysis, a physical quality test of cream preparations, and the $\mathrm{SPF}$ value. The $\mathrm{IC}_{50}$ value was calculated by linear regression

\section{RESULT AND DISCUSSION}

The results of the phytochemical screening test of purified corn hair extract using the tube method are presented in Table 3. It contained flavonoids, tannins, saponins, and alkaloids. The presence of flavonoids was due to an orange color change after adding concentrated $\mathrm{Mg}$ and $\mathrm{HCl}$ reagents. The purified extract also contains tannins characterized by a dark blue or blackish green color change after adding $1 \% \mathrm{FeCl}_{3}$. Saponin content was indicated by the presence of stable foam. The alkaloid content was indicated by the formation of a brown precipitate for Wegner's reagent, a white precipitate for Mayer's reagent, and a red-orange precipitate for dragendorff's reagent.

Table 3.The results of the phytochemical screening test of purified corn silk extract

\begin{tabular}{lllc}
\hline Compound group & Reactor & Result color & Information \\
\hline Flavonoids & $\mathrm{Mg}$, Concentrated $\mathrm{HCl}$ & Orange & Positive \\
Tannins & $\mathrm{FeCl}_{3}$ & Dark blue or blackish green & Positive \\
Saponins & Aquadest & There is foam & Positive \\
Alkaloids & Meyer's & White precipitate & Positive \\
& Dragendorff's & Orange-red sediment & Positive \\
& Wagner's & Brownish red sediment & Positive \\
\hline
\end{tabular}

Antioxidant activity testing was conducted using the DPPH method because the process was fast, sensitive, and using synthetic radical DPPH stable and soluble in polar solvents. Hydrazyl Picrile Diphenyl Molecules might react with hydrogen atoms from one molecule component of the sample to form the Diphenyl Pikril Hydrazine compound which might raise the absorbance value. The results of the antioxidant activity test were the $\mathrm{IC}_{50}$ level indicated that the ethanol extract and purified extract of corn hair produced $\mathrm{IC}_{50}$ values in the weak category, which can capture $50 \%$ free radicals compared to vitamin $\mathrm{C}$ via linear regression equation. The results of the $\mathrm{IC}_{50}$ level obtained can be seen in Table 4 . 
Table 4. The results of the antioxidant activity test of ethanol extract and purified corn silk extract

\begin{tabular}{ccccccc}
\hline $\begin{array}{c}\text { Concentra } \\
\text { tions } \\
(\mathbf{p p m})\end{array}$ & \multicolumn{2}{c}{ Absorbancy } & \multicolumn{2}{c}{$\%$ Inhibition } & \multicolumn{2}{c}{$\mathbf{I C}_{\mathbf{5 0}}(\boldsymbol{\mu g} / \mathbf{m L})$} \\
\cline { 2 - 7 } & Extract & $\begin{array}{c}\text { Purified } \\
\text { Extract }\end{array}$ & Extract & $\begin{array}{c}\text { Purified } \\
\text { Extract }\end{array}$ & Extract & $\begin{array}{c}\text { Purified } \\
\text { Extract }\end{array}$ \\
\hline 50 & 0.46 & 0.43 & 28.41 & 32.08 & & \\
100 & 0.44 & 0.42 & 30.08 & 34.33 & & \\
200 & 0.41 & 0.35 & 36.06 & 44.76 & $356.18 \pm 2.77$ & $256.55 \pm 2.68$ \\
300 & 0.38 & 0.29 & 41.04 & 54.61 & & \\
400 & 0.27 & 0.24 & 57.49 & 63.26 & & \\
\hline
\end{tabular}

Based on Table 4, it can be observed that there is a significant difference of $p<0.05$ in antioxidant activity after the T-test is held between ethanol extract and purified extract of corn silk. The $\mathrm{IC}_{50}$ value of corn silk extract was $356.18 \mu \mathrm{g} / \mathrm{mL}$ and the $\mathrm{IC}_{50}$ value of purified extract was $356.18 \mu \mathrm{g} / \mathrm{mL}$ with a comparison of antioxidant compounds, namely vitamin $\mathrm{C}$ which had an $\mathrm{IC}_{50}$ value of $37.5 \mu \mathrm{g} / \mathrm{mL}$ (Johnson et al., 2017). A compound is said to be a very strong antioxidant if the $\mathrm{IC}_{50}$ value is less than $50 \mu \mathrm{g} / \mathrm{mL}$, said to be a weak antioxidant if the $\mathrm{IC}_{50}$ value is more than 200 $\mu \mathrm{g} / \mathrm{mL}$ (Molyneux, 2004). The antioxidant activity of corn hair extract and purified extract was smaller than that of vitamin C using the DPPH method (Badarinath et al., 2010).

Table 5. The physical quality test result of anti-aging cream preparation of purified corn silk extract

\begin{tabular}{|c|c|c|c|c|c|c|}
\hline \multirow[b]{2}{*}{ Formula } & \multicolumn{5}{|c|}{ Preparation Evaluation } & \multirow[b]{2}{*}{$\begin{array}{c}\text { Cream } \\
\text { Type }\end{array}$} \\
\hline & Organoleptic & $\mathbf{p H}$ & Homogeneity & $\begin{array}{c}\text { Dispersion } \\
\text { (cm) }\end{array}$ & $\begin{array}{c}\text { Adhesion } \\
\text { (second) }\end{array}$ & \\
\hline FI $(1 \%)$ & $\begin{array}{ll}\text { Form: } & \text { Semisolid } \\
\text { Color: } & \text { Brownish } \\
\text { white } & \\
\text { Aroma: } & \text { Typical } \\
\text { of corn } & \\
\end{array}$ & $\begin{array}{c}5.2 \pm 0.2 \\
3\end{array}$ & Homogenous & $5.01 \pm 0.28$ & $4.45 \pm 0.00$ & $\begin{array}{l}\text { Oil in } \\
\text { water } \\
(\mathrm{O} / \mathrm{W})\end{array}$ \\
\hline $\mathrm{F} 2(5 \%)$ & $\begin{array}{l}\text { Form: Semisolid } \\
\text { Color: Brownish } \\
\text { Aroma: Typical } \\
\text { of corn }\end{array}$ & $\begin{array}{c}5.4 \pm 0.2 \\
5\end{array}$ & Homogenous & $5.03 \pm 0.28$ & $4.59 \pm 0.00$ & $\begin{array}{l}\text { Oil in } \\
\text { water } \\
(\mathrm{O} / \mathrm{W})\end{array}$ \\
\hline $\begin{array}{c}\mathrm{F} 3 \\
(10 \%)\end{array}$ & $\begin{array}{lr}\text { Form: } & \text { Semisolid } \\
\text { Color: } & \text { Dark } \\
\text { brown } & \\
\text { Aroma: } & \text { Typical } \\
\text { of corn } & \end{array}$ & $\begin{array}{c}5.4 \pm 0.3 \\
6\end{array}$ & Homogenous & $5.66 \pm 0.38$ & $4.87 \pm 0.01$ & $\begin{array}{l}\text { Oil in } \\
\text { water } \\
(\mathrm{O} / \mathrm{W})\end{array}$ \\
\hline
\end{tabular}

Here is a picture of corn silk purified extract cream. Based on the physical quality test, the greater the purified extract concentration used, the color was getting brown. The cream color can be seen in Figure 1. 


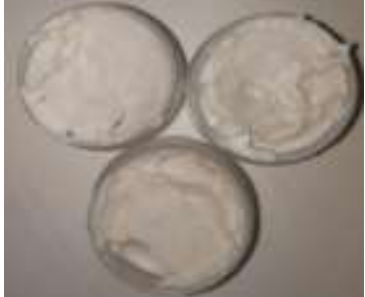

(A)

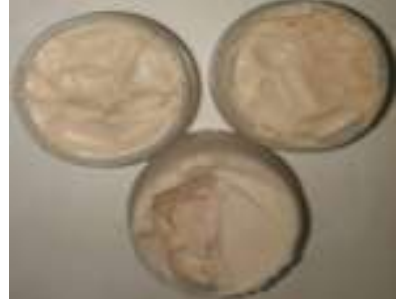

(B)

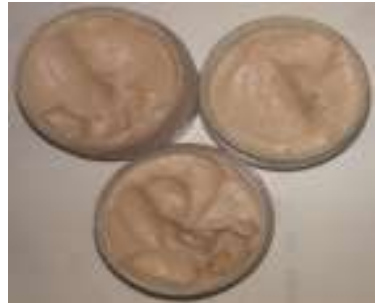

(C)

Figure 1. Image of corn silk purified extract cream formulation (A) formulation 1 extract concentration purified 1\% (B) formulation 2 concentration of $5 \%$ purified extract (C) formulation 3 concentration $10 \%$ purified extract

The physical quality test results of anti-aging cream preparations of purified corn silk extract can be seen in Table 5. Judging from the organoleptic form: semisolid, these creams have brownish white to brown and has a distinctive smell of corn. The higher the concentration of the formulation used, the darker the color. The $\mathrm{pH}$ cream test was carried out to find out how much the resulting $\mathrm{pH}$ value was. The suitability of the $\mathrm{pH}$ value affects the skin's acceptance of the preparation. $\mathrm{pH}$ preparations that are too acidic will cause skin irritation, while too alkaline can cause skin dryness (Tranggono and Latifah, 2007). The $\mathrm{pH}$ evaluation results fulfilled the requirement, which is around 4.5-6.5. The results of the dispersion test, according to the requirements, are around 5-7 cm, the greater the diameter value of the dispersive power, the more surface area the preparation can reach. The adhesion test aims to determine the time it takes for the preparation to adhere to the skin. Test results in adhesion for more than 4 seconds. The longer it takes, the longer the drug's working power. From the results of testing the type of cream with the electric delivery method, the type of cream produced is oil in water $(\mathrm{O} / \mathrm{W})$. When tested, the light turns on when the cable is dipped in the cream (Damogalad et al., 2013).

\section{Determination of the SPF level as an anti-aging parameter}

The SPF level is one of the parameters which states that the sample has the potential as a UV filter or not. The determination of the SPF level can be determined by UV spectrophotometry. Table 6 below presents the results of the calculation of the SPF level of the sample of purified corn silk extract cream.

Table 6. SPF level of purified corn silk extract cream

\begin{tabular}{cccccccc}
\hline I & EE & \multicolumn{2}{c}{ F1 } & \multicolumn{2}{c}{ F2 } & \multicolumn{2}{c}{ F3 } \\
\hline & & I & EE X 1 & I & EE X 1 & I & EE X 1 \\
\hline 290 & 0.02 & 0.21 & 0.01 & 0.34 & 0.01 & 0.77 & 0.01 \\
295 & 0.08 & 0.16 & 0.01 & 0.27 & 0.02 & 0.67 & 0.05 \\
300 & 0.29 & 0.14 & 0.04 & 0.24 & 0.07 & 0.62 & 0.18 \\
305 & 0.38 & 0.12 & 0.04 & 0.23 & 0.08 & 0.58 & 0.19 \\
310 & 0.19 & 0.11 & 0.02 & 0.23 & 0.05 & 0.56 & 0.10 \\
315 & 0.08 & 0.11 & 0.01 & 0.22 & 0.02 & 0.55 & 0.05 \\
320 & 0.02 & 0.11 & 0.00 & 0.22 & 0.00 & 0.54 & 0.01 \\
\hline Total & & 0.12 & & 0.24 & & 0.59 \\
\hline SPF & & 0.27 & & & & \\
\hline
\end{tabular}

The SPF level of several extract concentrations is obtained from the total sum of Erythema Efficiency multiplied by the Solar Rays Simulation Spectrum (EE x I) and Correlation Factor (CF), which is 10. The SPF level of each concentration can be seen in Table 6. The SPF level, which describes the product's ability to protect the skin from erythema, can be determined by in vitro. In vitro 
UV absorption activity test can be carried out using a UV spectroscopy technique measured in the UV light wavelength range (290-320nm) (Dutra et al., 2004). The SPF activity test of anti-aging cream preparations has good results. At a concentration of $1 \%$, it has an average SPF value of 1.27, the minimum protection range. At $5 \%$ concentration, it has an average SPF value of 2.41 in the minimum protection range. Meanwhile, the 10\% concentration has an SPF value of 5.94 in a moderate protection range. The higher the extract concentration in the cream, the higher the SPF value.

\section{CONCLUSION}

The purified extract of corn silk $\mathrm{IC}_{50}$ value of $256.66 \mu \mathrm{g} / \mathrm{mL}$ which was better than the ethanol extract of corn hair which had an $\mathrm{IC}_{50}$ value of $356.17 \mu \mathrm{g} / \mathrm{mL}$, including the weak antioxidant category. The quality evaluation of creams with concentration $1 \%, 5 \%$, and $15 \%$ showed that they had fulfilled requirements based on $\mathrm{pH}$, dispersion, and adhesion tests. The SPF activity on concentration $1 \%$, has an SPF value of 1.27 within the minimum protection range, concentration 5\%, has an SPF value of 2.41 in the minimum protection range, concentration $15 \%$ SPF value of 5.94 moderate protection range. The concentration of the purified extract of corn silk in the formulation increased in its SPF level.

\section{ACKNOWLEDGEMENT}

Authors would like to thank DP2M DIKTI for the funding support of the research project (Hibah Penelitian Dosen Pemula Nomor with grant number 06/SP2H/LT-MONO/IIK-BW/2020).

\section{REFERENCES}

Badarinath, A. V, Rao, K. M., Madhu, C., Chetty, S., Ramkanth, S., Rajan, T. V. S., \& Gnanaprakash, K. (2010). A Review on In-vitro Antioxidant Methods: Comparisions, Correlations and Considerations. International Journal of PharmTech Research, 2(2), 1276-1285.

Bernatoniene, J., Masteikova, R., Davalgiene, J., Peciura, R., Gauryliene, R., Bernatoniene, R., Majiene, D., Lazauskas, R., Civinskiene, G., Velziene, S., Muselik, J., \& Chalupova, Z. (2011). Topical application of calendula officinalis (L.): Formulation and evaluation of hydrophilic cream with antioxidant activity. Journal of Medicinal Plants Research, 5(6), 868-877.

Berneburg, M., Plettenberg, H., \& Krutmann, J. (2000). Photoaging of human skin. Photodermatology, Photoimmunology \& Photomedicine: Review Article, 16(6), 239-244.

Damogalad, V., Jaya Edy, H., \& Sri Supriati, H. (2013). Formulasi Krim Tabir Surya Ekstrak Kulit Nanas (Ananas Comosus L Merr) Dan Uji in Vitro Nilai Sun Protecting Factor (Spf). Pharmacon Jurnal Ilmiah Farmasi - Universitas Sam Ratulangi Manado, 2(02), 2302-2493.

Dutra, E. A., Kedor-Hackmann, E. R. M., \& Santoro, M. I. R. M. (2004). Determination of sun protection factor (SPF) of sunscreens by ultraviolet spectrophotometry. Revista Brasileira de Ciências Farmacêuticas, 40(3), 381-385.

Ekowati, D., \& Ningsih, D. (2014). Formulasi krim ekstrak buah mengkudu (Morinda citrifolia L.) sebagai antioksidan formulation of morinda citrifolia $L$. fruits extract as antioxidant cream. 11(1), 46-53.

Johnson, E. C., E. I., E., \& E. O. Archibong. (2017). Isolation and anti-oxidant potentials of parahydroxybenzaldehyde from the methanol leaf extract of aspilia africana(Pers.) C.D. adams (Asteraceae). Nigerian Journal of Pharmaceutical and Applied, 6(1), 26-32.

Laeliocattleya, \& Jati, \&. (2014). Potensi senyawa bioaktif rambut jagung (Zea Mays L.) hasil fraksinasi bertingkat menggunakan pelarut organik UN tuk tabir surya alami. Jurnal Teknologi Pertanian, 15(3), 175-184.

Liu, J., Lin, S., Wang, Z., Wang, C., Wang, E., Zhang, Y., \& Liu, J. (2011). Supercritical fluid extraction of flavonoids from Maydis stigma and its nitrite-scavenging ability. Food and 
Bioproducts Processing, 89(4), 333-339.

Maheshwar, G. H., Patil, B. S., \& Dhumal, P. (2010). Comparative sun protection factor determination of fresh fruits extract of Cucumber vs marketed cosmetic formulation. Research Journal of Pharmaceutical Biological and Chemical Sciences, 1(3), 55-59.

Molyneux. (2004). The use of the stable free radical diphenylpicryl-hydrazyl (DPPH) for estimating anti-oxidant activity. Songklanakarin Journal of Science and Technology, 26(May), 211-219.

Nariya, P. B., Bhalodia, N. R., Shukla, V. J., Acharya, R., \& Nariya, M. B. (2013). In vitro evaluation of antioxidant activity of Cordia dichotoma (Forst f.) bark. Ayu, 34(1), 124.

Nguyen, N., \& Rigel, D. S. (2005). Photoprotection and the Prevention of Photocarcinogenesis. In Cosmetic Formulation of Skin Care Products (pp. 177-190). CRC Press.

Nurhanan \& Rosli. (2012). Evaluation of Polyphenol Content and Antioxidant Activities of Some Selected Organic and Aqueous Extracts of Cornsilk (Zea Mays Hairs). Journal of Medical and Bioengineering, 1(1), 48-51. https://doi.org/10.12720/jomb.1.1.48-51

Rabima, \& Marshall, \&. (2017). Uji Stabilitas Formulasi Sediaan Krim Antioksidan Ekstrak Etanol 70\% Dari Biji Melinjo (Gnetum gnemon L.). Indonesia Natural Research Pharmaceutical Journal Universitas, 2(1), 107-121.

Scalbert, A., \& Williamson, G. (2000). Dietary intake and bioavailability of polyphenols. The Journal of Nutrition, 130(8), 2073S-2085S.

Tranggono, R. I., \& Latifah, F. (2007). Buku pegangan ilmu pengetahuan kosmetik. Jakarta: PT. Gramedia Pustaka Utama, 3(47), 58-59.

Walker, S. L., Hawk, J. L. M., \& Young, A. R. (2003). Acute and chronic effects of ultraviolet radiation on the skin. Fitzpatrick's Dermatology in General Medicine, 1, 1275-1282.

Zhang, F., Chen, B., Xiao, S., \& Yao, S. (2005). Optimization and comparison of different extraction techniques for sanguinarine and chelerythrine in fruits of Macleaya cordata (Willd) R. Br. Separation and Purification Technology, 42(3), 283-290. 
